\title{
THE TAXATION OF TWO \\ EARNER FAMILIES
}

\author{
Martin Feldstein \\ Daniel Feenberg
}

Working Paper No. 5155

\author{
NATIONAL BUREAU OF ECONOMIC RESEARCH \\ 1050 Massachusetts Avenue \\ Cambridge, MA 02138 \\ June 1995
}

Martin Feldstein is Professor of Economics at Harvard University and President of the National Bureau of Economic Research. Daniel Feenberg is a Research Associate of the NBER. Our earlier version of this paper was presented at a January 1995 NBER conference on Empirical Foundations of Household Taxation. We are grateful to Jeffrey Liebman, Harvey Rosen and other members of the NBER Public Economics Program and the Harvard-MIT Public Finance Seminar for comments on an earlier draft. This paper is part of NBER's research program in Public Economics. Any opinions expressed are those of the authors and not those of the National Bureau of Economic Research.

() 1995 by Martin Feldstein and Daniel Feenberg. All rights reserved. Short sections of text, not to exceed two paragraphs, may be quoted without explicit permission provided that full credit, including $(\mathcal{O}$ notice, is given to the source. 


\title{
THE TAXATION OF TWO \\ EARNER FAMILIES
}

\begin{abstract}
The present paper examines the efficiency and revenue effects of several alternative tax treatments of two earner families using estimates of the compensated elasticities of the labor supply of married women based on the experience with the 1986 tax rate reductions. The analysis of alternative options is based on the NBER TAXSIM model which has been modified to incorporate separate estimates of the earnings of husbands and wives. The marginal tax rates explicitly incorporate the Social Security payroll taxes net of the present actuarial value of future retirement benefits.

Three general conclusions emerge from analyzing the simulations of the various options presented in this paper. First, the existing high marginal tax rates on married women cause substantial deadweight losses that can be reduced by alternative tax rules that lower their marginal tax rates. Second, the behavioral responses to the lower marginal tax rates induce additional tax payments that offset large fractions of the "static" revenue losses. Third, there are substantial differences in cost-effectiveness among these options, i.e., in the revenue cost per dollar of reduced deadweight loss. Several of the options are sufficiently cost-effective that they could probably be combined with other ways of raising revenue to produce a net reduction in the deadweight loss of the tax system as a whole.

We are aware, however, that the current framework is very restrictive in three important ways. First, it ignores the response of the primary earner in the couple to any change in tax rates on spousal income. Second, it defines the labor supply response very narrowly in terms of participation and hours, excluding such important dimensions of labor supply as choice of occupation and of particular job, effort, location, travel requirements, risk bearing, assumption of responsibility, etc. More generally, taxes affect not only the labor supply of men and women but also change taxable income through changes in excluded income (fringe benefits, etc.) and in taxpayer deductions. These changes in taxable income are the key variable for influencing tax revenue and the deadweight loss of alternative tax rules. We plan to extend the current work to merge the evidence on the effects of taxes on the hours and participation of married women with the more general evidence on the sensitivity of taxable income to marginal tax rates.
\end{abstract}

Martin Feldstein

President

National Bureau of Economic Research

1050 Massachusetts Avenue

Cambridge, MA 02138
Daniel Feenberg

National Bureau of Economic Research

1050 Massachusetts Avenue

Cambridge, MA 02138 


\title{
The Taxation of Two Earner Families
}

\author{
Martin Feldstein and Daniel Feenberg*
}

More than two-thirds of married women under age 65 are now working outside the home. The tax treatment of married women is therefore a subject of substantial importance, not only to the women themselves but also to anyone concerned about the operation of our labor markets and the efficiency of our tax system.

The U.S. system of taxing the earnings of married women is very different from the methods used in most other major industrial nations. Among the OECD countries, the most common procedure is to tax each married taxpayer separately, thereby giving married women the same tax schedule that they would face if they were single. ${ }^{1}$ In contrast, the personal income tax in the United States taxes married couples on their combined income, thus not distinguishing between an increase in family income due to higher earnings of the husband and an increase in family income due to the wife's earnings. As a practical matter, the wife's marginal personal income tax rate on her first dollar of earnings is frequently the marginal income tax rate on her husband's last dollar of earnings.

\footnotetext{
${ }^{1}$ See Munnell (1980) for a summary of the tax treatment of married couples in other countries. These rules have been revised in several countries in recent years. Britain and Canada have recently adopted new rules in which married women are taxed separately.

*Martin Feldstein is Professor of Economics at Harvard University and President of the National Bureau of Economic Research. Daniel Feenberg is a Research Associate of the NBER. Our earlier version of this paper was presented at a January 1995 NBER conference on Empirical Foundations of Household Taxation. We are grateful to Jeffrey Liebman, Harvey Rosen and other members of the NBER Public Economics Program and the Harvard-MIT Public Finance Seminar for comments on an earlier draft.
} 
More important, however, the overall marginal tax rate of the married working woman is substantially higher than her husband's marginal tax rate because of the rules governing Social Security taxes and retirement benefits. Married women and married men are both subject to the same 15.3 percent payroll tax on earnings (including the portion paid by employers). Because the level of future retirement and survivor benefits depends on the level of earnings during working years, the effective Social Security tax rate is the difference between the statutory 15.3 percent and the present actuarial value of the future benefits that the employee can expect per additional dollar of his or her earnings. The rules governing retirement and survivor benefits mean that the expected present value of these benefits is generally substantially higher per marginal dollar of a husband's earnings than for a marginal dollar of a wife's earnings. Feldstein and Samwick (1992) show that, for a typical middle income married couple in their forties, the net Social Security OASI payroll tax rate in 1990 (excluding the disability and hospital insurance portions) was the full statutory rate of 11.2 percent for the wife but only about 3.8 percent for the husband. ${ }^{2}$

The current U.S. system of taxing married women has been criticized for three weaknesses. First, the high marginal tax rates on married women inappropriately distort their decisions about whether to work and, if they work, about how much to work. The basic theory

\footnotetext{
${ }^{2}$ The difference reflects the fact that husbands generally have higher average lifetime earnings than their wives and that retiree wives are entitled to the greater of their own benefit and 50 percent of their husband's benefit. Since wives generally outlive their husbands, it is also important that a surviving wife is entitled to the higher of the benefits based on her own lifetime earnings and her husband's full benefit. Feldstein and Samwick (1992) present calculations of the net present value of retirement benefits for a variety of different combinations of income, demographic status and discount rates.
} 
of optimal taxation implies that the total deadweight loss of the tax system is reduced if marginal tax rates are lower on those individuals whose labor supply is more sensitive to marginal tax rates. Since there is substantial evidence that the labor supply elasticities of married women are substantially greater than the labor supply elasticities of their husbands, ${ }^{3}$ the theory of optimal taxation implies that married women should be taxed at a lower marginal tax rate than their husbands. ${ }^{4}$ In contrast to this optimality condition, the Social Security tax and benefit rules make the marginal tax rates on married women's earnings substantially higher than on their husbands' earnings. ${ }^{5}$ The calculations developed in this paper show that the overall deadweight loss of the tax system could probably be reduced by lowering the marginal tax rate of married women even though there is a deadweight loss associated with the taxes needed to replace the lost revenue.

${ }^{3}$ See for example the survey by Triest (1990) and the more recent study by Eissa (1994).

${ }^{4}$ This conclusion is emphasized by Boskin and Sheshinski (1983). The relevant labor supply elasticities are the compensated elasticities of labor supply with respect to the net of tax share, i.e., to one minus the marginal tax rate. The proposition that applying a lower marginal tax rate to married women than to their husbands reduces the overall deadweight loss of the tax system depends on the cross-elasticities of labor supply as well as on the own elasticities; to the extent that there is evidence on this cross elasticity (see, e.g., Triest (1990) and Hausman and Ruud (1984)) it appears to be sufficiently small so that it does not change the basic result.

A more general analysis of the deadweight loss of the income tax recognizes that it depends on distortions to the pattern of consumption (in favor of deductible items like mortgage interest and excludable items like fringe benefits) and to the nature of labor supply (effort, location, risk taking, etc..in addition to participation and hours). Feldstein (1995a) shows that this more comprehensive measure of deadweight loss can be evaluated in terms of the elasticity of taxable income with respect to the net of tax share. We plan to use the broader measure to evaluate alternative tax treatments of two-earner families in a future study.

5Previous discussions have ignored the important effect of net Social Security taxes; see, e.g., Rosen (1987). 
A second common criticism of the current system is that it imposes a "marriage penalty" on some married couples by taxing them more than the same two individuals would pay on the same income if they were single ${ }^{6}$. The marriage penalty is seen as unfair because it violates the basic principle of taxing equals equally by imposing different tax burdens on two otherwise identical couples. Although it could be argued that the two couples are not identical because one couple has chosen to live together without marrying while the other couple has called upon the state to provide the legal benefits of marriage, it seems contrary to general public policy to impose a fiscal charge on individuals for choosing to marry rather than living together without marrying. Moreover, as living together without marriage becomes more common, the effect of the marriage tax on the decision to marry is also likely to become more substantial. ${ }^{7}$

Finally, the current system is considered unfair because it imposes the same tax burden on a married couple with one earner as it does on a two-earner couple with the same income. ${ }^{8}$ The two earner couple will in general have more total hours of work and less of the untaxed home services of the second earner.

${ }^{6}$ See the discussions in Feenberg and Rosen $(1983,1994)$, Munnell (1980) and Rosen (1987).

${ }^{7}$ Although there appears to be no direct research on this point, it is noteworthy that in 1992 there were 3.3 million unmarried couples (defined as two unrelated adults of the opposite sex sharing the same household) and that 1.1 million of these couples had at least one child under the age of 15 . This compares to approximately 56 million married couples. Among 25 to 44 year olds, there were 2.0 million unmarried couples and 26 million married couples, a ratio of 7.6 percent.

${ }^{8}$ In fact, because of the Social Security tax and benefit rules, a couple with two earners is likely to pay more net tax than a couple with one earner and the same total income. The two earner couple will pay more in tax (net of the present value of future Social Security benefits) unless the husband and wife have the same earnings in every year. 
The present paper examines the efficiency and revenue effects of several alternative tax treatments of two earner families. These options also have the effect of reducing the marriage penalty and of reducing the tax on two-earner couples relative to the tax on single-earner couples with the same total income. In addition to these new options, the present paper is distinguished from previous contributions to the analysis of two-earner families by four technical improvements:

(1) The analysis uses new, and we believe more reliable, estimates of the compensated elasticities of the labor supply of married women based on the experience with the 1986 tax rate reductions. ${ }^{9}$

(2) The marginal tax rates explicitly incorporate the Social Security payroll taxes net of the present actuarial value of future retirement benefits.

(3) The analysis of alternative options is based on the NBER TAXSIM model which has been modified for this study to incorporate separate estimates of the earnings of husbands and wives.

(4) Explicit estimates of the effects of the alternative options on the deadweight loss

${ }^{9}$ These elasticities have been estimated by Eissa (1994). We believe that her differences-indifferences estimates are more reliable than previous estimates based on cross-section variation in after-tax wage rates. Since previous estimates of labor supply behavior have been shown to be sensitive to the choice of functional form, it is significant that the differences-in-differences approach avoids the need to specify an explicit functional form. A further advantage of this approach is that it is not necessary to impute a wage rate to the women who are out of the labor force.

Eissa's overall estimated supply elasticity, including the effects of both participation and hours, is not substantially different from the central tendency of the general body of previous work. See, e.g., the recent survey by Triest (1990). The confirmation of these earlier crosssection results by the more reliable differences-in-differences estimates is nevertheless very reassuring. 
of the tax system are presented. These reflect separately the changes in labor force participation and in average hours among those who are working. The analysis is based on the Harberger-Browning local approximation and therefore does not require any assumption about the form of the utility function.

The first section of the paper presents a simple heuristic calculation that indicates that reducing the marginal income tax rate on a representative married women to what it would be if she were single would substantially reduce the deadweight loss of the tax system as a whole. Section two extends this simple analysis to reflect changes in labor force participation as well as in average hours among those who are employed. This disaggregated analysis confirms the general estimates of the simpler model of the previous section.

The third section then describes the augmented TAXSIM model that is used to evaluate a variety of alternative options for the entire population of married taxpayers. The options are specified and the simulation results are presented in section four. There is a brief concluding section.

\section{The Effect of Reducing the Marginal Tax Rate on Married Women: A Simplified}

\section{Calculation}

In 1994, a married woman in a couple with taxable income between $\$ 38,000$ and $\$ 91,850$ had a marginal federal personal income tax rate of 28 percent. In addition, she and her employer paid a Social Security payroll tax (including the Medicare portion) of 15.3 percent for which she can generally expect to receive little or no incremental benefit (Feldstein and Samwick, 1992). She was also likely to face a state marginal income tax rate of 5 percent or higher. Her 
combined marginal tax rate was therefore approximately 48 percent of her taxable income. ${ }^{10}$

Most married women would have faced a marginal federal personal income tax rate of only 15 percent if they were taxed as single individuals on their own income." If they were taxed in this way, their total marginal tax rate would be reduced from 48 percent to 35 percent.

This section presents a simplified but very detailed estimate of the effect of reducing the tax rate on married women from 48 percent to 35 percent. The analysis suggests that this rate reduction would reduce the deadweight loss by substantially more than the decline in revenue. More specifically, the parameter values based on the estimated behavior of labor supply imply that, for such women, the deadweight burden of the tax would decline by $\$ 2.74$ for each dollar of revenue loss. Since there are other ways of raising revenue with a substantially smaller relative deadweight loss, reducing the marginal tax rate on married women could be part of a broader tax reform that reduces the overall deadweight loss of the tax system.

Reducing the marginal income tax rate on married women would also address (but not completely remedy) the other two criticisms of the existing tax rules. It would reduce the marriage penalty and would tax a two earner couple less than a single earner couple with the

\footnotetext{
${ }^{10}$ Because the employer's half of the 15.3 percent payroll tax is not included in the individual's taxable income, the combined tax of 48 percent is equivalent to $48 /(1.0765)=45$ percent of the full pretax wage. The deadweight loss depends therefore on this marginal tax rate although applied to a tax base that is larger by a factor of 1.0765 . Since the net effect is to reduce the deadweight loss by less than one-tenth, we postpone taking this into account until we get to the detailed TAXSIM calculations in section 4. This makes the illustrative calculations in the first two sections easier to follow.

${ }^{11}$ Under the tax schedule for single individuals, the taxpayer would pay a 15 percent marginal tax on taxable income up to $\$ 22,750$. Since the median money income of year-round full-time female workers was only $\$ 22,167$ in 1992, a substantial majority of working wives in 1994 would have earnings below $\$ 22,750$.
} 
same income.

Our analysis focuses on the effect of taxes on labor force participation and average hours. A more comprehensive analysis would recognize that changing tax rates affects taxable income through a number of other channels, including the intensity of work effort, the form of compensation, the use of tax deductible expenditures, and various aspects of non-labor income and expenses. ${ }^{12}$ By focusing just on the traditional labor supply measures of participation and hours we understate the deadweight loss of the current situation and the potential gain from reform. We return to this subject in the concluding section.

The current analysis uses the labor supply elasticities recently estimated in Eissa's (1994) study of the response of married women to the 1986 tax rate reductions. In contrast to previous cross-section studies, Eissa used the natural experiment of the 1986 rate reductions to study how married women responded to differences in the marginal rate reductions associated with differences in their husbands' pre-1986 income levels. This differences-in-differences approach, based on successive Current Population Surveys, found a compensated elasticity of the participation rate with respect to the net of tax wage (i.e., to (1-t)w where $t$ is the marginal tax rate and $w$ is the pretax wage) of 0.42 and a compensated elasticity of the hours worked among those who are employed of $0.45 .^{13}$ Although the next section will study the separate responses

12 See Feldstein (1993 and 1995a) for a more complete discussion of the importance of this broader definition of taxpayers' responses to higher marginal tax rates.

${ }^{13}$ These estimates use the differences-in-differences framework combined with regression equations to control for demographic differences to reduce the bias and the variance of the parameter estimates. The raw differences-in-differences estimates are 0.35 for participation and 0.38 for hours so the effect of the regression adjustment is a small increase in the estimated elasticities. Elasticities are calculated at the mean participation rate (0.464) and mean hours of 
of participation and hours, the simpler model in the current section uses a single overall elasticity of total hours with respect to the net of tax share.

The effect of the tax rate reduction on revenue depends on the corresponding uncompensated elasticity of total hours with respect to the net of tax share. The usual Slutsky decomposition implies

$$
\mathrm{dL} / \mathrm{d}(1-\mathrm{t})=\{\mathrm{dL} / \mathrm{d}(1-\mathrm{t})\}_{\text {COMP }}+(\mathrm{dL} / \mathrm{dy}) \mathrm{dy} / \mathrm{d}(1-\mathrm{t})
$$

where $\mathrm{L}$ is hours worked, $\mathrm{t}$ is the marginal tax rate, and dy is the rise in income that results from the tax rate reduction with no behavioral response. Multiplying both sides by $(1-\mathrm{t}) / \mathrm{L}$ gives the corresponding elasticity expressions:

$$
[(1-t) / L][d L / d(1-t)]=[(1-t) / L]\{d L / d(1-t)\}_{C O M P}+[(1-t) / L](d L / d y)(d y / d(1-t)) .
$$

Writing $\eta$ for the uncompensated supply elasticity on the left hand side of equation (2) and $\varepsilon$ for the compensated supply elasticity (the first term on the right hand side) and noting that dy $/ d(1-t)=-d y / d t=w L$ where $w$ is the pretax wage, allows us to rewrite equation (2) as

$$
\eta=\varepsilon+(1-t) w d L / d y .
$$

Eissa's estimates of compensated elasticities of participation and hours of 0.45 and 0.42 imply a total compensated labor supply elasticity of about $\varepsilon=0.9$. Previous estimates imply that the income effect, i.e. the net of tax expenditure on leisure per dollar of additional exogenous income, $-(1-\mathrm{t}) \mathrm{w}(\mathrm{dL} / \mathrm{dy})$, is approximately 0.10 , implying that $\eta=\varepsilon-0.10=0.80$.

With this information in mind, recall the traditional Harberger-Browning formula for the

those who worked ( 1283 hours per year) among the women with high income husbands. 
deadweight loss of the income tax with a marginal tax rate of $t$ is: ${ }^{14}$

(4) $\mathrm{DWL}=0.5 \mathrm{t}^{2} \mathrm{wL} /(1-\mathrm{t})$.

Thus, with a marginal tax rate of 0.48 , the deadweight loss is DWL $=0.5(.48)^{2} \varepsilon$ wL $(1-.48)^{-1}$. The corresponding formula for the reduction in the deadweight loss if the marginal tax rate is reduced form 48 percent to 35 percent is

$$
\begin{aligned}
\Delta \mathrm{DWL} & =-0.5\left[(.48)^{2}-(.35)^{2}\right] \varepsilon \mathrm{wL} /(1-.48) . \\
& =-0.093 \mathrm{wL} .
\end{aligned}
$$

If the woman pays the same tax rate on all of her income, a change in the marginal tax rate alters her tax liability at the rate of ${ }^{15}$

$$
d(t w L) / d t=[1-(t /(1-t)) \eta] w L
$$

A tax reduction of $\mathrm{dt}=0.13$ from $\mathrm{t}=.48$ implies a revenue loss of $0.034 \mathrm{wL}$.

Thus, every dollar of revenue loss reduces the deadweight loss by $0.093 / 0.034=\$ 2.74$.

Stated differently, this calculation implies that the total cost (including both the resource transfer and the deadweight loss) of taxing married women at 48 percent rather than 35 percent is $\$ 3.74$ for each extra dollar of revenue collected because the higher rate is used. Reducing the marginal

\footnotetext{
${ }^{14}$ Browning (1987) showed that the original Harberger (1964) formula for the deadweight loss [ $\left.\mathrm{DWL}=0.5 \mathrm{t}^{2} \varepsilon \mathrm{wL}\right]$ has to be modified when the elasticity and the labor supply are not measured at the undistorted no-tax point. Since the elasticity estimate that we use and the initial labor supply are both measured at the with-tax distorted point, the traditional Harberger formula must be modified by dividing by (1-t). See Browning (1987, page 13) and the derivation of equation 7 below.

${ }^{15}$ If the 48 percent initial marginal tax rate is paid on only part of her income, the revenue loss from reducing her tax rate to 35 percent would be less while the improvement in the deadweight loss would be unchanged. We return to this in the text below.
} 
tax rate from 48 percent to 35 percent would reduce the total deadweight loss of the tax system as a whole if the decline in revenue can be offset from some other source with a deadweight loss of less than $\$ 2.74$ per dollar of revenue.

The estimated loss of revenue caused by the reduction of the tax rate is based on the assumption that the woman's entire income was initially taxed at 48 percent. Recall that a 48 percent marginal tax rate for married women is based on a 28 percent federal marginal income tax rate and that the 28 percent rate begins at $\$ 38,000$ of taxable income for a married couple. With one child and the standard deduction, this is equivalent to a gross income of $\$ 51,700$. As a result, in many cases only a fraction of the wife's initial earnings will be subject to the full 48 percent rate. This would not affect the reduction in the deadweight loss since the deadweight loss depends only on the marginal tax rate. But when only a fraction of the women's income is originally taxed at the higher rate, the net revenue loss is reduced and may even be reversed to produce a revenue gain.

Consider for example a couple with one child in which the husband initially earns $\$ 40,000$ and the wife initially earns $\$ 25,000$. Their gross income is $\$ 65,000$ and their taxable income is $\$ 51,300$. She initially pays a 48 percent tax on $\$ 13,300$ of her earnings (the excess over $\$ 38,000$ ) and a 35 percent tax on the remaining $\$ 11,700$. Reducing her tax rate to 35 percent on all of her income only reduces her tax liability by $\$ 1,729$ on her original earnings. With a marginal tax rate reduction from 48 percent to 35 percent and an uncompensated elasticity of 0.8 , she increases her pretax earnings from $\$ 25,000$ to $\$ 30,000$ and pays a tax of $\$ 1750$ on the incremental earnings. Her net tax payment therefore actually rises by $\$ 21$. The reduction in the deadweight loss remains unchanged at $0.093 \mathrm{wL}=\$ 2325$. Thus in this realistic 
case the deadweight loss reduction is substantial even though there is no revenue loss at all.

Before exploring these issues further with the help of the TAXSIM model's simulations, we consider in detail a more analytically complete model that distinguishes the separate effects of the tax rate on women's participation decisions and on the average hours worked by those who do participate.

\section{The Effects of Participation and Hours Responses to Marginal Tax Rate Reductions}

Calculating the deadweight loss and the revenue effects of tax-induced changes in the married women's labor force participation rate is quite different from calculating the deadweight loss and revenue effects of tax-induced changes in average working hours among the employed women. It is useful therefore to consider each component of total labor supply separately and then to combine the separate results. We also show how the change in the deadweight loss and in revenue are related to the household's welfare gain.

\subsection{The Effect of the Hours Distortion on Deadweight Loss, Revenue and Household Welfare}

We begin with the effects of the marginal tax rate on the hours worked by those wives who are employed. To illustrate the calculation we again assume that a representative married woman initially pays a marginal tax rate of 48 percent on her entire earnings and that this is reduced to 35 percent by the change in tax rules. As already noted, if the 48 percent rate applies to only part of her earnings, this assumption causes us to overstate the revenue loss but not the improvement in the deadweight loss. Following Eissa (1994) we take the elasticity of hours with respect to the net of tax share to be $\varepsilon_{\mathrm{H}}=0.45$. Since the change in the deadweight loss 
and in the revenue are both proportional to the initial wage income, we need not specify numerical values for either the wage $(w)$ or the initial hours $\left(\mathrm{H}_{1}\right)$.

Figure 1 illustrates the reduction in the deadweight loss as the marginal tax rate is reduced from $t_{1}=0.48$ to $t_{2}=0.35$ and hours increase on the compensated supply curve from $H_{1}$ to $\mathrm{H}_{2}$.

Figure 1

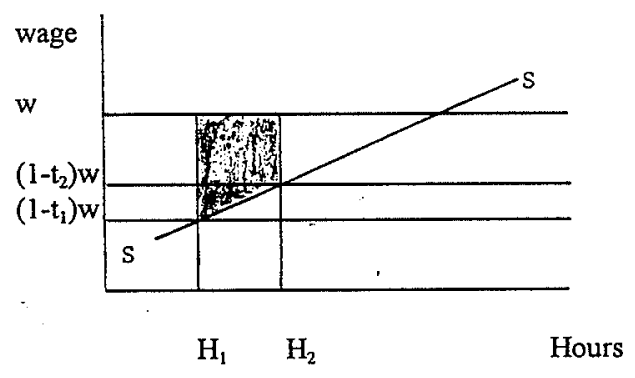

The deadweight loss reduction is equivalent to the shaded trapezoid bounded by the labor supply curve (SS) and the wage line (w) between the initial hours $\mathrm{H}_{1}$ and the final hours $\mathrm{H}_{2}$ :

$$
\begin{aligned}
& \Delta \text { DWL }=-\left\{t_{2} w\left(H_{2}-H_{1}\right)+0.5\left(t_{1}-t_{2}\right) w\left(H_{2}-H_{1}\right)\right\} \\
& =-\left[t_{2} w+0.5\left(t_{1}-t_{2}\right) w\right][d H / d(1-t) w]\left(t_{1}-t_{2}\right) w \\
& =-\left[t_{2}+0.5\left(t_{1}-t_{2}\right)\right]\left(t_{1}-t_{2}\right)\left(1-t_{1}\right)^{-1} \varepsilon_{H} w_{1}
\end{aligned}
$$

where $\varepsilon_{H}=\left[\left(1-t_{1}\right) w / H_{1}\right][d H / d(1-t) w]$ Substituting $t_{1}=0.48, t_{2}=0.35$, and $\varepsilon_{\mathrm{H}}=0.45$ implies $\Delta \mathrm{DWL}=-.047 \mathrm{w} \mathrm{H}_{1}$.

The revenue effect of reducing the marginal tax rate from $t_{1}$ to $t_{2}$ is

(8) $\Delta \operatorname{Rev}=\left(t_{2}-t_{1}\right) w H_{1}+t_{2} w \Delta H$ 
where $\Delta \mathrm{H}$ is the increase in hours implied by the uncompensated labor supply function. That is, the revenue effect is the combination of the revenue loss from the reduced tax rate applied to the initial labor income offset in part by the additional revenue that results from the increased number of hours worked. Following the usual Slutsky decomposition,

$$
\Delta H=\{d H / d(1-t)\}_{C O M P} d(1-t)+(d H / d y) d y
$$

where dy is the decrease in taxes with no behavioral response: $d y=\left(t_{1}-t_{2}\right) w_{1}$. Thus

$$
\Delta H=\varepsilon_{H} \quad H_{1}[d(1-t) /(1-t)]+w^{-1}(d w H / d y)\left(t_{1}-t_{2}\right) w H_{1}
$$

Since those who are not initially participating do not have any income effect, the entire effect of a change in exogenous income is concentrated on those who are already working. Previous estimates of this income effect suggest $\mathrm{dwH} / \mathrm{dy}=-0.15 .{ }^{16}$ Substituting this into equation (10) and using $\varepsilon_{\mathrm{H}}=0.45$ and $\mathrm{d}(1-\mathrm{t}) /(1-\mathrm{t})=0.25$ implies $\Delta \mathrm{H}=[.45(.25)-.15(.13)] \mathrm{H}_{1}=.093 \mathrm{H}_{1}$. Finally, substituting this expression for the change in hours into equation (8) to obtain the change in revenue: $\Delta \operatorname{Rev}=\left(t_{2}-t_{1}\right) w H_{1}+t_{2} w \Delta H=[-0.13+.35(.093)] w H_{1}=$ $-0.0975 \mathrm{w} \mathrm{H}_{1}$.

Thus, among those who are already working, the reduction in the marginal tax rate from 48 percent to 35 percent reduces revenue by $0.0975 \mathrm{w} \mathrm{H}_{1}$ and reduces the deadweight loss by $0.047 \mathrm{w} \mathrm{H}_{1}$.

When there is already a tax in place, the reduction in the deadweight loss that follows from a decline in the tax rate is not the same as the direct gain in the welfare of the individual

\footnotetext{
${ }^{16}$ This is analogous to the simplifying assumption in the previous section that $(1-t) d w L / d y=$ 0.10 .
} 
household. If the decline in the deadweight loss is accompanied by a loss of revenue to the Treasury, that revenue is still a gain to the household although not to society as a whole. The reduction of the deadweight loss therefore understates the gain to the household. Conversely, if the decline in the deadweight loss is accompanied by a rise in revenue, the decline of the deadweight loss overstates the gain to the household. ${ }^{17}$ Figure 1 shows that the net welfare gain to the woman has two components. First, on her initial earnings she would pay less tax; her net income would rise by $\left(t_{1}-t_{2}\right) w H_{1 .}$. To this extent, her gain is the Treasury's loss. But the increased hours that she works are compensated at a net of tax wage $\left(1-t_{1}\right) w$ that exceeds her required supply price along the SS compensated supply curve. Her surplus on these incremental hours is the triangle $0.5\left(t_{1}-t_{2}\right) w\left(H_{2}-H_{1}\right)$.

Thus, the working woman's total gain is

$$
\begin{aligned}
& \Delta W=\left(t_{1}-t_{2}\right) w H_{1}+0.5\left(t_{1}-t_{2}\right) w\left(H_{2}-H_{1}\right) . \\
& =\left(t_{1}-t_{2}\right) w H_{1}+0.5\left(t_{1}-t_{2}\right) \varepsilon_{H}\left[\left(t_{1}-t_{2}\right) /\left(1-t_{1}\right)\right] w_{1} .
\end{aligned}
$$

Substituting numerical values for $\mathrm{t}_{1}=0.48, \mathrm{t}_{2}=0.35$ and $\varepsilon_{\mathrm{H}}=0.45$ yields $\Delta \mathrm{W}=0.137 \mathrm{wH}_{\mathbf{1}}$.

The additional hours that the woman works increases her welfare by an amount equal to a little more than 5 percent of her pretax labor income.

Note that the triangle that represents the woman's surplus gain from working more hours is equal to the decline in the deadweight loss reduced by the gain in revenue that the government receives $t_{2} w\left(H_{2}-H_{1}\right)$ as a result of the increased work along the compensated supply curve.

\footnotetext{
${ }^{17}$ More precisely, these statements are true if the revenue changes associated with changes in labor supply are measured along the compensated labor supply curve. This is explained further in the text that follows.
} 
The government's net revenue gain (excluding the revenue impact of the income effect on work) is this increased revenue $\left\{t_{2} w\left(H_{2}-H_{1}\right)\right\}$ minus the revenue lost on the initial earnings $\left\{\left(t_{1}-t_{2}\right) w\right.$ $\left.\mathrm{H}_{1}\right\}$. Thus the woman's gain is equal to the decline in the deadweight loss minus the net revenue gain of the government (excluding the revenue impact of the income effect on work.)

We now turn to the corresponding calculations for the effect of the tax on participation and then combine the effects for the two groups.

\subsection{The Effect of the Participation Distortion on Deadweight Loss, Revenue and Household}

\section{Welfare}

A reduction in the tax rate faced by married women increases the number of women who choose to work. More formally, it increases the number of women for whom the net of tax wage exceeds the reservation wage. Eissa (1994) estimates that the elasticity of participation with respect to the net of tax share is 0.42 , implying that reducing the tax rate from 48 percent to 35 percent would increase the participation rate from 0.46 (in her sample) to about $0.51 .^{18}$

There is of course no change in the deadweight loss among women who remain out of the labor force after the reduction in the tax rate. All of the deadweight loss reduction among those who are initially nonparticipants is among those women who go from being nonparticipants to being participants.

Modeling the reduction in the deadweight loss is complicated by two factors. First, we do not know how many hours would be worked by those women who would enter the labor

\footnotetext{
${ }^{18}$ This reflects the fact that there is no income effect since those women who are not working initially do not have a change in tax revenue unless they change their behavior. 
force if their tax rate were reduced. In the current analysis we therefore assume that those who enter the labor force in response to the lower marginal tax rate would then choose to work the same number of hours that previous participants work, $\mathrm{H}_{2}$.

The second complication is that we do not know the reservation wage of those who shift into the labor force when the tax rate declines. All we know is that the net reservation wage is higher than $\left(1-t_{1}\right)$ w since they did not work at that wage and that it is not higher than $\left(1-t_{2}\right) w$ since they do work at that wage. Fortunately, although the precise magnitude of the deadweight loss depends on level of the reservation wage, the analysis in this section and the simulations in section 4 show that for many possible tax changes the uncertainty about the reservation wage produces only a relatively small uncertainty about the magnitude of the deadweight loss. We calculate the deadweight loss at the extreme values of the reservation wage (i.e., at $\left(1-\mathrm{t}_{1}\right) \mathrm{w}$ and $\left.\left(1-t_{2}\right) w\right)$.

These issues are illustrated in Figure 2. The pretax wage is shown as w. The individual initially faces a net wage of $\left(1-t_{1}\right) w$ at which she chooses to work zero hours. Her reservation wage is shown as $\left(1-t^{*}\right) \mathrm{w}$ where $\mathrm{t}^{*}$ is unknown to us as analysts. Increases in the net wage above

Figure 2

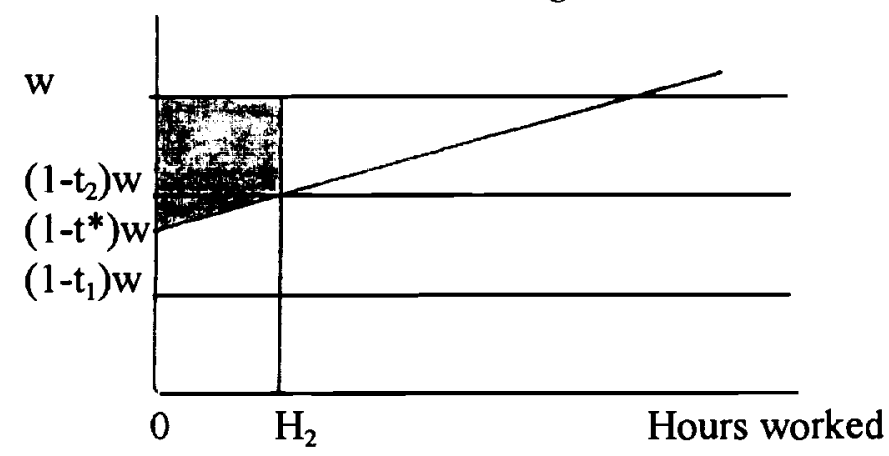


(1-t*)w induce her to move to higher desired hours along the labor supply curve $S$ that starts at the point with zero hours and net wage $\left(1-t^{*}\right) \mathrm{w}$ and passes through the point with coordinates (1-t $t_{2}$ )w and $\mathrm{H}_{2}$. We do not observe intermediate points on that labor supply curve because her labor supply jumps to $\mathrm{H}_{2}$ hours when the available wage jumps to $\left(1-\mathrm{t}_{2}\right) \mathrm{w}$.

The reduction of the deadweight loss consists of the shaded trapezoid bounded by the gross wage level and the labor supply line between labor supply of zero and $\mathrm{H}_{2}$. For all of those who are induced to participate, the deadweight loss falls by at least the rectangle $\mathrm{t}_{2} \mathrm{wH}_{2}$, the revenue that the government collects when people are no longer discouraged from participating in the labor force. In addition, the deadweight loss falls by the amount indicated by the triangle with area $0.5\left(t^{*}-t_{2}\right) w H_{2}$. Since the reservation wage is unknown, we will write this as $0.5 \lambda\left(\mathrm{t}_{1}-\mathrm{t}_{2}\right) w \mathrm{H}_{2}$ where $0<\lambda<1$.

Combining the two parts shows that the total change in the deadweight loss is given by:

$$
\begin{aligned}
\Delta \mathrm{DWL} & =-\left\{\mathrm{t}_{2} \mathrm{wH}_{2}+0.5 \lambda\left(\mathrm{t}_{1}-\mathrm{t}_{2}\right) \mathrm{w} \mathrm{H}_{2}\right\} \\
= & -\left[\mathrm{t}_{2}+0.5 \lambda\left(\mathrm{t}_{1}-\mathrm{t}_{2}\right)\right] \mathrm{w} \mathrm{H}_{2}
\end{aligned}
$$

Since $t_{2}=0.35$ and $0.5\left(t_{1}-t_{2}\right)=0.065$, the uncertainty about the magnitude of the reservation wage cannot influence the deadweight loss estimate by as much as 20 percent (i.e., $0.065 / 0.35=$ $0.19)$ for those women who are initially nonparticipants. For those who become employed, the reduced deadweight loss lies between $.35 \mathrm{w} \mathrm{H}_{2}$ and $.415 \mathrm{w} \mathrm{H}_{2}$. More general tax reforms can create greater uncertainty about the reservation wage and the deadweight loss if the resulting value of $t_{2}$ is substantially less than $t_{1}$, e.g., a separate filing system that reduces the personal income tax for the married women to zero.

To aggregate this with the deadweight loss calculated for those who were initially 
employed and changed their hours (i.e., the $0.047 \mathrm{w} \mathrm{H}_{1}$ reported above ) the post-change hours $\mathrm{H}_{2}$ in equation 12 must be restated in terms of the initial hours, $\mathrm{H}_{1}$. Since equation (10) implies that the increase in hours among participants was equal to $0.093 \mathrm{H}_{1}$, it follows that $\mathrm{H}_{2}=1.093$ $\mathrm{H}_{1}$ and therefore that the reduced deadweight loss among those who were not initially in the labor force but who are induced by the tax reduction to join the labor force lies between .35 (1.093) $\mathrm{w} \mathrm{H}_{1}=.38 \mathrm{w} \mathrm{H}_{1}$ per new participant and $0.45 \mathrm{w} \mathrm{H}_{1}$ per new participant. The actual aggregation is discussed below after we comment on the revenue effect of the reduced tax rate for this group.

The revenue effect of the lower tax rate for those who are initially not in the labor force is unambiguously positive. Since none of these women were employed before the tax rate reduction, there is no decrease in initial tax revenue. The revenue effect for each woman who shifts from not working to working $\mathrm{H}_{2}$ hours is

$$
\Delta \operatorname{Rev}=\mathrm{t}_{2} \mathrm{w} \mathrm{H}_{2}
$$

Restating $\mathrm{H}_{2}$ as $1.093 \mathrm{H}_{1}$ implies that $\Delta \mathrm{Rev}=.38 \mathrm{H}_{1}$ for each new participant.

The welfare gain to the individual household depends on the woman's reservation wage. If the reservation wage is almost exactly equal to the net wage after the tax reduction $\left(t^{*}=t_{2}\right)$, virtually the entire reduction in the deadweight loss accrues to the government in the form of increased revenue. This is a special case of the statement made earlier that, for those women who were initially working, the gain to the woman is the reduction in the deadweight loss minus the government's net revenue gain (excluding the revenue impact of the income effect on work effort.) In this case, the reduced deadweight loss is just the government revenue gain so there is no gain (i.e., no reduced deadweight loss) for the woman. Of course, if the reservation wage is 
lower, there will be a net gain to the woman equal to the area of the triangle $0.5\left(t^{*}-t_{2}\right) \mathrm{wH}_{2}$ in figure 2 and the deadweight loss reduction exceeds the government's revenue gain by that amount. $^{19}$

\subsection{The Combined Effect on Deadweight Loss and Revenue for All Married Women}

The total of the effect on those who are initially employed and the effect on those who enter the labor force depends on the initial distribution between those who are in the labor force and those who are not and the increase in the fraction in the labor force that results from the tax rate reduction. To illustrate this calculation we use the figures based on Eissa's sample: 46 percent of women are initially in the labor force so that, with a participation elasticity of 0.42 with respect to the net of tax rate, the tax rate reduction form 48 percent to 35 percent raises the participation rate to 51 percent.

We can now put the pieces together and calculate the reduced deadweight loss per 100 married women. Since the deadweight loss per employed woman is reduced by $0.047 \mathrm{w} \mathrm{H}_{1}$ and there are 46 employed women per 100 married women, the reduced deadweight loss from this source is $0.047(46) \mathrm{w} \mathrm{H}_{1}=2.16 \mathrm{w} \mathrm{H}_{1}$ per 100 women. Similarly, since the deadweight loss is reduced by between $0.38 \mathrm{w} \mathrm{H}_{1}$ and $0.45 \mathrm{w} \mathrm{H}_{1}$ for each woman who enters the labor force and 5 women per 100 married women are induced to enter the labor force by the reduced tax rate, the reduced deadweight loss among initial nonparticipants is equal to between $1.90 \mathrm{w} \mathrm{H}_{1}$ and 2.25 $\mathrm{w}_{1}$ per 100 women. Combining these two shows that the overall deadweight loss reduction per

\footnotetext{
${ }^{19}$ In the case of women who were previously nonparticipants, there is no income effect of the tax rate reduction.
}

2earner.7 (050895) 
100 married women is between $4.06 \mathrm{w} \mathrm{H}_{1}$ per 100 married women and $4.41 \mathrm{w} \mathrm{H}_{1}$ per 100 married women. In this case, the uncertainty introduced by not knowing the reservation wage is less than 10 percent of the total reduced deadweight loss.

The revenue effect of the reduced tax rate can be calculated in the same way. Since lowering the tax rate from 0.48 to 0.35 reduces tax revenue among employed women by 0.0975 w $\mathrm{H}_{1}$ and there are 46 employed women per 100 married women, the revenue loss among those who are initially employed is $4.48 \mathrm{w} \mathrm{H}_{1}$ per 100 married women. Among those who are not initially employed, the rate reduction induces a revenue gain of $0.38 \mathrm{w} \mathrm{H}_{1}$ per newly employed person. Since the lower tax rate induces 5 women per 100 married women to join the labor force, the increased revenue is $1.90 \mathrm{w} \mathrm{H}_{1 .}$. The combined revenue effect is therefore a net loss of $2.58 \mathrm{w} \mathrm{H}_{1}$ per 100 married women.

Comparing the change in the deadweight loss and the change in the revenue shows that reducing the marginal tax rate from 48 percent to 35 percent would reduce the deadweight loss by at least $4.06 \mathrm{w} \mathrm{H}_{1}$ per 100 married women while reducing revenue by $2.58 \mathrm{w} \mathrm{H}_{1}$ per 100 married women. In rough terms, there is $\$ 1.57$ of deadweight loss avoided for every dollar of lost revenue. Equivalently, there is a real net resource loss of $\$ 1.57$ for every dollar of revenue raised by taxing married women at 48 percent instead of 35 percent. Since the revenue loss could presumably be offset with a much smaller deadweight loss by other tax changes, a reform that reduces the marginal federal income tax rate on married women from 28 percent to 15 percent (and therefore reduces the overall marginal tax rate from 48 percent to 35 percent) could increase the overall efficiency of the income tax.

It is worth emphasizing that, among women who are initially out of the labor force, the 
participation effect not only reduces the deadweight loss but actually increases revenue at the same time. Since some previous estimates of the response of married women to taxes suggest that the participation response is even more important than the 0.42 elasticity that we have assumed $^{20}$, our calculations here may underestimate the relative advantage of lowering the marginal tax rate on married women. This is reinforced to the extent that the initial average tax rate on those married women who are working is less than their marginal rate so that the rate reduction involves a smaller loss of revenue.

\section{Adapting the TAXSIM Model to Analyze the Effects of Tax Reforms on Married}

\section{Women}

Although the detailed examination of a group of representative middle class married women in section 2 indicates that there may be substantial efficiency gains from changing the tax rules that apply to two earner families, it is important to go beyond these simplified examples and consider how changes in tax rules would affect the entire population of married women. Microsimulation analysis with the NBER's TAXSIM model permits taking into account a variety of complexities, including the initial pattern of labor force participation and the relations between wives' earnings and other family income.

To carry out this analysis, the usual TAXSIM model had to be augmented in several ways. These changes are described in the current section. The TAXSIM model combines a

\footnotetext{
${ }^{20}$ Triest (1990) suggests that the response of total hours to increases in the net of tax share is about the same as Eissa's estimates but that almost all of that response comes through increased participation. The TAXSIM simulations presented below include an explicit analysis of the sensitivity of the results to the estimated elasticity.
} 
stratified random sample of more than 100,000 tax returns provided by the Internal Revenue Service with a computer program that incorporates the current income tax rules and the ability to modify those rules and calculate the effects of alternative tax rules on taxable income, deadweight loss, etc. The model can reflect the behavioral responses of taxpayers to changes in tax rates and tax rules. As noted above, the behavioral responses that we study in the current paper focus on changes in married women's labor supply through changes in participation and in average hours worked. $^{21}$

The TAXSIM model used in the current paper incorporates the Treasury's public use sample of individual tax returns for 1991, the most recent sample that is currently available. Since this study is concerned exclusively with alternative tax rules for married women, the usual TAXSIM sample is reduced to married couples. These tax returns are augmented with data from the March 1992 Current Population Survey (CPS) in order to have information on the separate earnings of husbands and wives and to go beyond the very limited information on taxpayer age provided in the Treasury's public use sample (whether the taxpayer claims one or more age exemptions for being over 65). When this information has been added to the tax return file we can use earlier estimates by Feldstein and Samwick (1992) of the present value of Social Security retirement and survivor benefits to calculate the net marginal Social Security payroll tax

${ }^{21}$ Although the basic TAXSIM model and data are very similar to those used by the Office of Tax Analysis at the Treasury Department and by the staff of the Congressional Joint Tax Committee, the nature of our simulations is very different. The official revenue estimators impose on themselves the restriction that the behavioral responses that they estimate must not change nominal GDP. See Feldstein $(1994,1995 \mathrm{~b})$ for a discussion of the current procedures of the revenue estimators and of the reasons for looking beyond the narrow range of behavior that they do take into account. 
for each individual.

Data from the CPS is added to the tax return information by matching each couple in the tax file to a couple in the CPS. To do this, the CPS couples are cross-classified into 109 types by four criteria: total wages of the husband and wife together; interest and dividend income; number of children; and whether the taxpayer and/or the spouse is over age 65. Each TAXSIM record is then matched to a CPS record randomly selected from among the CPS records whose wage category, interest and dividend income category, number of dependents, and age 65-plus status match the TAXSIM record exactly. The earnings of the husband and of the wife is then imputed to the TAXSIM record in a way that preserves the taxpayer's combined wage and salary income (line 1 of the form 1040) while making the ratio of the wife's wage and salary to the combined wage and salary conform to the ratio in the CPS data. The CPS record was also used to impute the age of the primary earner.

The resulting data for 1991 were "aged" to 1994 to reflect the expected increase in the number of tax returns and the rise in incomes. In addition, the 1994 baseline incomes were adjusted to reflect taxpayers' assumed responses to the four major aspects of the 1993 tax legislation: ${ }^{22}$ (1) the increase in the top marginal tax rate from 31 percent to 36 percent on taxable incomes between $\$ 140,000$ and $\$ 250,000$ and to 39.6 percent on taxable incomes over $\$ 250,000 ;{ }^{23}$ (2) the elimination of the $\$ 135,000$ ceiling on the taxbase for the Medicare (HI) payroll tax; (3) the changes in the alternative minimum tax; and (4) the changes in the Earned

\footnotetext{
${ }^{22}$ This adjustment follows the procedures described in Feldstein (1995a).

${ }^{23}$ These are the changes for married couples filing joint tax returns. Other changes were made for single individuals and other filing categories.
} 
Income Tax Credit.

The TAXSIM analysis of alternative tax rules for married women follows the simplified assumption of focusing exclusively on the participation and hours decisions of the married women. We ignore other changes in their behavior that alter taxable income as well as all changes in the behavior of men and single women. We assume also that the pretax wage rate is constant. The two key behavioral elasticities, based on Eissa (1994), are the compensated elasticities of hours with respect to the net of tax wage among women who work under existing tax rules $\left(\varepsilon_{\mathrm{H}}=0.45\right)$ and the elasticity of the participation rate with respect to the net of $\operatorname{tax}$ share $\left(\varepsilon_{\mathrm{P}}=0.42\right)$. As discussed above, we take the effect of exogenous income on the demand for leisure hours consumed to be 0.15 dollars of foregone wage income per incremental dollar of exogenous income.

Because the TAXSIM model does not currently incorporate 1994 state income tax rates, they are ignored in the current analysis. This reduces the initial and final overall tax rate levels and therefore decreases the reduction in the deadweight loss that results from reducing the tax rate.

In contrast to the simplified analyses of sections 2 and 3 , we now incorporate a more realistic treatment of the Social Security tax to reflect the present actuarial value of future benefits. We also recognize that the taxpayer's income is defined net of the employer's share of the Social Security payroll tax. Each $\$ 100$ of taxable wage income up to a maximum taxable wage level of $\$ 60,600$ for 1994 is subject to an extra tax of $\$ 7.65$. This indicates that the full gross wage is $\$ 107.65$ per $\$ 100$ of taxable wage income, implying that $\$ 100$ of taxable wage 
income corresponds to a marginal product of labor of $\$ 107.65$.

We now make this more precise by describing the explicit calculation used to evaluate the deadweight loss and revenue effects of the existing tax rules and of potential alternative tax rules. We follow the framework of section 2 by dividing the sample of married couples into those with a working spouse (i.e., a wife with wage and salary income in 1994) and those in which the wife was not in the labor force.

\subsection{The Subsample of Working Wives}

The initial marginal tax rate of the working wife is:

$$
t_{1}=t_{1}^{\text {PIT }}+t_{1}{ }^{H I}+t_{1}^{S S N}
$$

where $t_{1}{ }^{P I T}$ is the marginal tax rate under the personal income tax, $t_{1}{ }^{H I}$ is the employeremployee combined payroll tax for health insurance (Medicare), and $t_{1}$ SSN is the net employeremployee payroll tax for Social Security. The subscript 1 indicates that this is the initial tax rate; a subscript 2 is used to denote the post-reform tax rate. Each of these components needs some further comment.

The marginal tax rate under the personal income tax is defined as a fraction of the full gross wage (the marginal product of labor). If the woman earns less than the $\$ 60,600$ (the Social Security maximum covered earnings in 1994), the employer pays a payroll tax of 7.65 percent, implying that each dollar of taxable income corresponds to $\$ 1.0765$ of marginal product. A 28 percent statutory tax rate on taxable income therefore corresponds to a tax rate of $0.28 / 1.0765=$ 0.26 on the marginal product of labor. For such an individual, we therefore write $\mathrm{t}_{1}^{\mathrm{PIT}}=0.26$. If the woman's income exceeds $\$ 60,600$, she is no longer subject to the Social Security payroll tax 
on marginal earnings but is still subject to the 2.9 percent Medicare payroll tax. For such women, the employer pays a marginal payroll tax of 1.45 percent, implying that a 28 percent tax on taxable income is equivalent to $\mathrm{t}_{1}^{\mathrm{PIT}}=0.28 / 1.0145=0.276$ on the marginal product of labor.

The $\mathrm{HI}$ payroll tax is $\mathrm{t}_{1}{ }^{\mathrm{HI}}=0.029 / 1.0765=0.0269$ if the woman's income is less than $\$ 60,600$ and is $t_{1}{ }^{\mathrm{HI}}=0.029 / 1.0145=.0286$ if the woman's income exceeds $\$ 60,600$.

The Social Security payroll tax that influences the taxpayer's behavior should reflect the present actuarial value of the future benefits that are accrued by earning an additional dollar of wage and salary income. ${ }^{24}$ For married women, assessing the value of this incremental benefit is complicated by the fact that a woman may claim benefits at retirement based on her own earnings history or may claim benefits as her husband's dependent spouse. Since a dependent spouse's benefits are equal to 50 percent of the benefits of the primary retiree, a wife will choose to receive benefits as a retired worker (rather than as a dependent spouse) if her own lifetime earnings record implies a benefit level greater than 50 percent of her husband's benefit level ${ }^{25} \mathrm{~A}$ second complication in calculating the present actuarial value of benefits is that a surviving spouse can receive benefits equal to 100 percent of her husband's benefit or can receive the benefit to which she is entitled as a retired worker. Most married women will find it advantageous to claim such survivor benefits and therefore will get no extra benefit during the years that she is a widow for the taxes that she paid while she was working.

\footnotetext{
${ }^{24}$ The simplified calculations of sections 1 and 2 ignored this aspect of the Social Security $\operatorname{tax}$.

${ }^{25}$ The analysis is complicated further by her ability to retire earlier than her husband, claiming benefits at that time on her own record, and then shift to dependent spouse status when her husband retires.
} 
Feldstein and Samwick (1992) estimated the present actuarial value of benefits for employees classified by age, sex, income and prospective benefit status (e.g., male retiree with dependent spouse; female retiree without dependents). Although it is not possible for us to reflect

all of the complexities of the Social Security benefit rules on the basis of the information that we have in the augmented TAXSIM file, we do use the Feldstein-Samwick calculations to estimate the present actual value of retirement benefits for each woman in our sample. ${ }^{26}$ For this purpose, we classify a woman as a potential retired worker who will claim benefits on the basis of her own earnings only if her current wage and salary places her at a point in the earnings distribution at which her individual benefit would exceed the benefit to which she would be entitled as a dependent spouse.

The marginal Social Security tax rate $t_{1}$ SSN is the difference between the gross Social Security tax rate $(0.124$ if her wage and salary income is less than the $\$ 60,600$ Social Security maximum and zero if her wage and salary income is higher) and the present actuarial value of benefits (pavb) derived by Feldstein and Samwick divided by the marginal product of labor per dollar of taxable income. Thus a woman with wage and salary income below $\$ 60,600$ has $\mathrm{t}_{1}^{\mathrm{SSN}}=$ (.124- pavb) / 1.0765. If her income exceeds the maximum taxable earnings under Social Security, $\mathrm{t}_{1}^{\mathrm{SSN}}=0$.

Equation 7 in section 2.1 shows that the change in the deadweight loss due to a change in the marginal tax rate on married women workers is given by

\footnotetext{
${ }^{26}$ The Feldstein-Samwick estimates do not include the value of disability benefits. Such benefits are about 10 percent of the total Social Security OASDI benefits.

2earner.7(050895) 


$$
\Delta \mathrm{DWL}=-\left[\mathrm{t}_{2}+0.5\left(\mathrm{t}_{1}-\mathrm{t}_{2}\right)\right]\left(\mathrm{t}_{1}-\mathrm{t}_{2}\right)\left(1-\mathrm{t}_{1}\right)^{-1} \varepsilon_{\mathrm{H}} \mathrm{E}_{1}
$$

where $t_{1}$ is the marginal tax rate described in equation $14, t_{2}$ is the corresponding marginal tax rate after the change in tax rules, $\varepsilon_{\mathrm{H}}$ is the compensated elasticity of hours with respect to the net of tax share, and $E_{1}$ is the woman's initial wage and salary income (corresponding to $\mathrm{w}_{1}$ of equation 7). TAXSIM evaluates equation (15) for each individual in the subsample of married women who work.

Calculating the revenue effect for each woman of a change in the tax rule can be conceptually divided into two parts: (1) the "static" tax change and (2) the effect on revenue of the induced change in earnings. The static tax change calculation begins with the total tax paid under existing tax rules, $T_{1}$, defined to exclude the payroll taxes on the husband's earnings. Thus the $T_{1}$ tax measure consists of the couple's initial personal income tax liability, plus the woman's initial $\mathrm{HI} \operatorname{tax}\left(0.029 \mathrm{E}_{1}\right)$ and the woman's initial Social Security payroll tax $\left[.124 \mathrm{E}_{1}\right.$ if $\mathrm{E}_{1}<$ $\$ 60,600$ and zero if $\left.E_{1}>\$ 60,600\right]$. The tax rules and tax rates are then revised and the TAXSIM program is used to recalculate the corresponding tax liability under the new rules and rates but with no changes in the initial incomes. We denote this tax burden under the new rules with the old income as $T_{2}$. The static change in the individual's tax is therefore $T_{2}-T_{1}$.

Although behavior is appropriately modeled in terms of the Social Security tax net of the present actuarial value of benefits, the Treasury's current revenue receipts depend only on the gross Social Security tax. Since government budget accounting generally ignores the present value of future taxes and outlays, we calculate both a net revenue and a gross revenue change that ignores the present actuarial value of future benefits. More specifically, we take the value 
of benefits into account in modeling individual behavior but then calculate the revenue implications based only on the gross tax. Section four presents alternative revenue estimates based on net and gross Social Security revenue.

Calculating the revenue effect of the individual change in earnings is based on equation (10) of section 2 . Since we assume that the wage rate per hour (w) is fixed, we can multiply all of the terms in equation (10) by w and therefore rewrite equation (10) in terms of earnings $(\mathrm{E}=\mathrm{wH})$ as

$$
\Delta E=\varepsilon_{H} E_{1}\left(t_{1}-t_{2}\right) /\left(1-t_{1}\right)+(d E / d y)\left(T_{1}-T_{2}\right)
$$

Equation (16) states the change in earnings as the sum of the compensated percentage change in hours multiplied by the initial level of earnings plus the income effect on earnings of the reduction in taxes with no behavioral response. As we noted earlier, previous research indicates the income effect is commonly estimated at about $\mathrm{dE} / \mathrm{dy}=-0.15$. The total revenue effect is therefore calculated by TAXSIM with the new tax rules and tax rates applied to the new level of earnings, $E_{1}+\Delta E$.

\subsection{The Subsample of Wives Initially Out of the Labor Force}

If the proportion of women under age 65 who are initially employed is $p_{1}$, the participation elasticity implies

$$
\Delta p=p_{1} \varepsilon_{P}\left(t_{1}-t_{2}\right) /\left(1-t_{1}\right)
$$

For any woman who is initially out of the labor force, the probability of entering the labor force is $\Delta p /\left(1-p_{1}\right)$. 
In calculating the deadweight loss and the revenue, our baseline assumption is that women who shift from being out of the labor force to being employed have the same pretax earnings when they are employed as the average earnings of the previously employed women under the new tax rules (i.e., the mean of $E_{1}+\Delta E$ ) ${ }^{27}$ We also present simulation results that assume that new entrants have only one half of the average earnings of previously employed women under the new tax rules.

From the analysis of section 2.2 , the reduced deadweight loss for new participants lies between a lower bound that is just equal to the tax that they pay under the new tax rules and an upper bound that is an unweighted average of that tax and the tax that they would pay on the same earnings under the old tax rules. ${ }^{28}$ TAXSIM therefore derives the lower bound on the change in the deadweight loss for those who shift into employment by calculating, under the new tax rules, the change in the couple's personal income tax associated with the wife's new employment plus her payroll tax payments. The upper bound on the change in the deadweight loss is calculated by averaging the lower bound figure with the taxes that would occur under the old tax rates and rules with the new participation and hours.

Our TAXSIM procedure multiplies the potential reduced deadweight loss for each woman who is initially out of the labor force by the probability that she will enter the labor

\footnotetext{
${ }^{27} \mathrm{This}$ is analogous to the assumption of section 2.2 that those women who enter the labor force work the same $\mathrm{H}_{2}$ hours as previous employees. This subject could obviously benefit from more extensive analysis based on panel data. It may also be possible to refine the analysis of the probability of shifting from out of the labor force to employment to reflect information about the individual's spouse, children, age, etc that are in the TAXSIM file but not currently taken into account.
}

${ }^{28}$ See equation 12 of section 2.2 and note that $\lambda=1$ implies $\Delta \mathrm{DWL}=-0.5\left(\mathrm{t}_{1}+\mathrm{t}_{2}\right) \mathrm{wL}$. 
force. TAXSIM can therefore simply add these probability-weighted deadweight loss reductions over all of the observations in the sample of nonworking wives.

The revenue changes and deadweight loss reductions for the two subsamples taken together give the total changes in revenue and deadweight loss for all married women.

\section{Tax Reform Options}

In this paper, we analyze four different types of alternatives to the current method of taxing two-earner couples. Section 4.1 discusses proposals to reinstate the second earner deduction that was repealed in the 1986 Tax Reform legislation. Section 4.2 considers other innovations within the framework of joint filing that have the effect of reducing the marginal tax rate on married women. Section 4.3 then discusses separate filing as an alternative to the current joint filing rule. Finally, section 4.4 analyzes the effect of eliminating the extra marginal tax rate imposed by Social Security on married women ${ }_{2}$

For each option, we calculate the effects on earnings, on tax revenue, and on the deadweight loss of the tax system. Finally, we examine the impact on the marriage penalty as well as on the marriage bonus. For the second earner deduction, we also discuss the sensitivity of the analysis to alternative values of the labor supply elasticities and present disaggregated results by income class.

Before looking at any of the alterative tax rules, we present estimates of the current tax situation of married taxpayers that can serve as a background for putting the effects of the individual options in perspective. Table 1 shows 1994 average and aggregate tax revenues for married taxpayers (with tax liabilities greater than zero) in each taxable income class starting 
with $\$ 10,000$ of adjusted gross income. ${ }^{29}$ The table presents the personal income tax (PIT), the employee-employer payments of the Social Security payroll $\operatorname{tax}\left(\mathrm{OASDH}{ }^{\mathrm{G}}\right)$, and the total federal tax (the sum of the personal income tax and the employer-employee payroll tax).

In the aggregate, these 51 million married taxpayers paid total personal income taxes of $\$ 384$ billion, approximately 70 percent of the estimated personal income taxes paid by all taxpayers. Similarly, these couples and their employers paid OASDHI payroll tax of $\$ 292$ billion, about 63 percent of the estimated 1994 total OASDHI receipts for all taxpayers.

Table 2 presents comparable baseline figures for the marriage penalty, showing, by AGI class, the number of couples that are now paying a marriage penalty (i.e., that pay more personal income tax than they would if they were unmarried) and the average penalty among such couples. Similarly, the table shows the number of couples that are now enjoying a marriage bonus (i.e., paying less personal income tax than they would if they were not married) and the average bonus for such couples. In the aggregate, there are now 20 million couples ( 40 percent) paying marriage penalties that total $\$ 37$ billion while there are also 27 million couples (54 percent) receiving marriage bonuses that total $\$ 41$ billion. Thus for married taxpayers as a whole, the effect of marriage is to reduce taxes. Among taxpayers with AGIs over $\$ 50,000$, however, the opposite is true.

29A married couple with adjusted gross incomes below $\$ 10,000$ owes no tax because the combination of two personal exemptions and the standard deduction for a joint return together exceed $\$ 10,000$. 


\section{Table 1}

Distribution of Aggregate and Average Tax Revenues Joint Tax Returns. 1994

$\begin{array}{lll}\text { AGI } & \begin{array}{c}\text { Number } \\ \text { Of Returns }\end{array} & \text { Pverages per Return } \\ (000) & \text { Income } \\ & \text { Tax }\end{array}$

Aggregates
Personal OASDHI $^{\mathrm{O}}$ PIT + OASDHI
Income
Tax

$\begin{array}{lr}\$ 10- & 9258 \\ \$ 25- & 16968 \\ \$ 50- & 16408 \\ \$ 100- & 3389 \\ \$ 200+ & 795\end{array}$ 166

$$
1759
$$

1926

7702

$3092 \quad 4610$

$8398 \quad 8495$

$23640 \quad 12609$

16893

36249

$144491 \quad 15225$

159717

Tax

Total 50731

$7575 \quad 5754$

13329

$\begin{array}{rr}1.5 & 16.2 \\ 52.4 & 78.2 \\ 137.7 & 139.3 \\ 80.1 & 42.7 \\ 114.8 & 12.1 \\ & \\ 384.2 & 291.9\end{array}$

17.8

130.6

277.1

122.8

126.9

Individual amounts are averages per return. Totals are in billions of dollars. All figures for 1994.

Estimates are based on TAXSIM model calculations using the 1991 Treasury Public Use Sample aged to 1994 levels. 


\subsection{The Second Earner Deduction}

A 10 percent "second earner deduction" was a feature of the income tax law from 1981 until it was repealed in the Tax Reform Act of 1986. It allowed the couple to deduct from taxable income 10 percent of the wage and salary income of the spouse with the lower earnings, up to a maximum deduction of $\$ 3,000$. For married women with wage and salary income below $\$ 30,000$, the deduction of ten percent of earnings is equivalent to a ten percent reduction in the tax rate on those earnings. ${ }^{30}$

In addition to analyzing the original pre-1986 plan, we recognize that nominal per capita income has nearly doubled since the $\$ 30,000$ limit was set in 1981 . We therefore consider the effect of raising the maximum deduction to $\$ 5,000$ (i.e, a deduction of 10 percent of the first $\$ 50,000$ of wage and salary income).

The first row of Table 3 presents the results of our analysis of the original second earner deduction with the $\$ 3,000$ limit. The reduced marginal tax rate would cause the pretax earnings of married women with earnings below $\$ 30,000$ to increase while those with incomes over $\$ 30,000$ would decline (by $\$ 450$ each) because of the income effect. The aggregate effect of this would be a $\$ 5.7$ billion net increase in pretax earnings, shown in column 1 .

${ }^{30}$ Since the second earner deduction reduces taxable income but not adjusted gross income, it does not affect any of the tax deductions that are themselves dependent on the level of AGI. The second earner deduction is discussed in detail with an explicit example in Feldstein (1995c) as an illustration of the importance of taking taxpayer labor supply behavior into account in evaluating tax proposals. 
Table 2

\section{Couples with Marriage Penalties and Marriage Bonuses}

$\begin{array}{ll}\text { AGI } & \begin{array}{c}\text { Number } \\ \text { Class }\end{array} \\ \text { of Returns } \\ (000) & (000)\end{array}$

Couples with Marriage Penalty

Number Average Amount

Couples with Marriage Bonus

$\$ 10-\quad 9258$

1527

7774

8328

2164

$\$ 50-\quad 16408$

399

1729

1413

1542

3062

9648

$\$ 200+\quad 795$

1833

Number

Average Amount

Mean

20270

37.1

26975

730

7102

1332

9156

2122

$\begin{array}{ll}1224 & 4079\end{array}$

$368 \quad 4080$

Total 50731

(40.0 percent)

(53.2 percent)

1533

Individual amounts are averages per return. Totals are in billions of dollars. All figures for 1994.

Estimates are based on TAXSIM model calculations using the 1991 Treasury Public Use Sample aged to 1994 levels. 


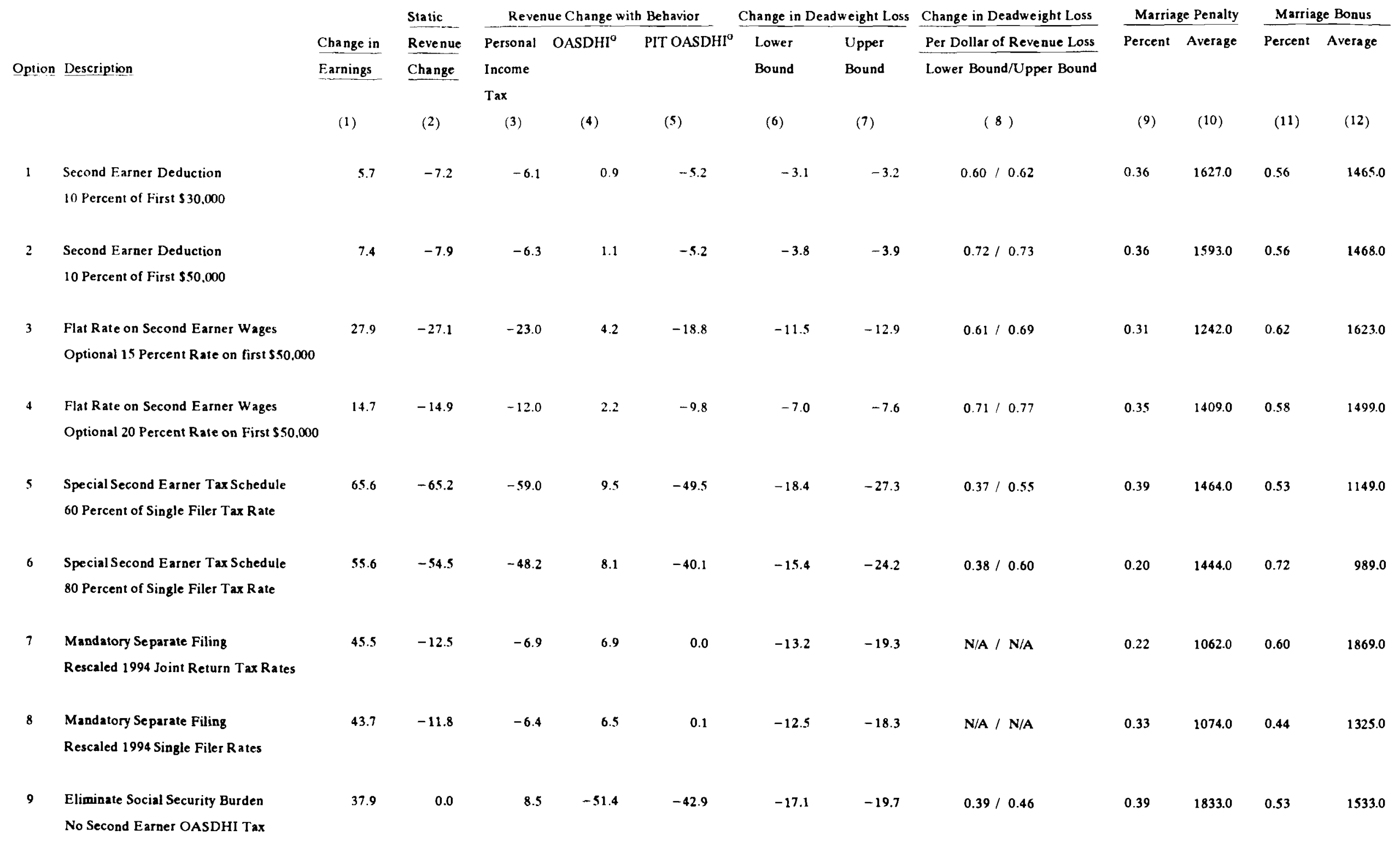

Amounts are in billions of dollars. All figures for 1994. Estimates are based on TAXSIM model calculations using the 1991 Treasury Public Use Sample aged to 1994 levels. 
This increase in earnings is reflected in the difference between the "static revenue change" shown in column 2 and the "revenue change with behavior" shown in columns 3,4 and 5 . With no change in behavior, the static revenue loss is $\$ 7.2$ billion. The $\$ 5.7$ billion net increase in earnings cuts the loss of personal income tax revenue from $\$ 7.2$ billion to $\$ 6.1$ billion, shown in column $3 .^{31}$ In addition, the increased earnings that result from greater labor force participation and greater working hours also increase the payroll taxes that these women and their employers pay. This revenue gain is shown in column 4 as the positive change in $\mathrm{OASDHI}^{\mathrm{G}}$; the superscript $\mathrm{G}$ identifies this as the change in the full payroll tax revenue without any offset for the present actuarial value of future retirement benefits. The total increase in OASDHI payroll tax revenue that results from the higher earnings is $\$ 0.9$ billion (column 4 ), bringing the net revenue loss of the second earner deduction down to $\$ 5.2$ billion (column 5). ${ }^{32}$ In this case, the static revenue loss overstates the estimated net loss by $\$ 2.0$ billion or 38 percent. Columns 6 and 7 report the aggregate change in the deadweight loss of the tax system,

\footnotetext{
${ }^{31}$ It is wrong to interpret the ratio of the additional income tax to the additional earnings (0.193) as an average marginal tax rate of 19.3 percent since the $\$ 5.7$ billion earnings increase is the net effect of earnings increases of women with lower earnings and earnings decreases of women with higher earnings (and typically higher marginal tax rates).

${ }^{32}$ The difference between the gross OASDHI revenue and the corresponding revenue net of the present value of future benefits is very small because most married women, and particularly those with the lower earnings who increase their earnings in response to the deduction, will claim retirement benefits as dependent spouses. We estimate that the present value of the benefits offsets only about 10 percent of the extra gross payroll tax revenue. If the present value of future Social Security retirement benefits is taken into account, the net OASDHI revenue is reduced to $\$ 0.8$ billion and the overall net revenue loss rises to $\$ 5.3$ billion.
} 
giving both a lower bound estimate and an upper bound estimate. ${ }^{33}$ Since the reductions in marginal tax rates are relatively small, the range of possible reservation wages for new participants is also small. Our inability to know the reservation wage precisely therefore does not affect any conclusions about the desirability of reviving the second earner deduction. We also report (column 8) the ratio of the reduction in the deadweight loss to the net revenue loss ( $\$ 5.2$ billion), a ratio of 0.60 with the lower bound estimate and 0.62 with the upper bound estimate, implying that each dollar of revenue loss reduces the deadweight loss of the tax system by between 60 cents and 62 cents.

The final four columns shows the effect of the second earner deduction on the marriage penalty and bonus. The second earner deduction reduces the marriage penalty for all taxpayers who currently face a marriage penalty since all married couples receive some tax reduction, including those with incomes over $\$ 30,000$. Column 9 shows that the percentage of couples with a marriage penalty falls from the initial 40 percent shown in table 2 to 36 percent. The average dollar amount per couple with a marriage penalty also falls from $\$ 1833$ to $\$ 1627$. Finally, the couples with a marriage bonus rises from the initial 54 percent with an average bonus of $\$ 1533$ to 56 percent with an average bonus of $\$ 1465$.

The second simulation (shown in the second row of Table 3) examines the effect of a

${ }^{33}$ The lower and upper bounds on the deadweight loss reduction reflect the uncertainty of the reservation wage of those who shift from nonparticipants to participants (as explained in section 2 of this paper). The lower bound estimate corresponds to $\lambda=0$ in equation 11 and the upper bound estimate corresponds to $\lambda=1$. The lower bound assumes that the woman is just indifferent between working and not working after the tax change while the upper bound estimate assumes that she was just indifferent between working and not working before the tax change. In the lower bound case, all of the reduced deadweight loss accrues in the form of increased tax revenue. 
more generous second earner deduction: a deduction of 10 percent of earnings up to a $\$ 5,000$ limit. The surprising feature of this analysis is that the plan with the higher ceiling dominates the original second earner deduction: it has the same revenue loss but a greater reduction in the deadweight loss. This occurs because the pre-1986 second earner deduction plan shown in row one has no favorable effect on the incentives of women with initial earnings above $\$ 30,000$ while nevertheless reducing the tax that they pay. Raising the ceiling to $\$ 50,000$ provides favorable incentives to enough women with initial earnings between these two limits to make the additional earnings of these higher earning women pay for the entire increased static revenue loss.

More specifically, the higher deduction limit raises the static revenue loss by approximately $\$ 700$ million, from $\$ 7.2$ billion to $\$ 7.9$ billion (column 2 ). But the induced rise in earnings of $\$ 7.4$ billion instead of $\$ 5.7$ billion (column 1), brings enough extra tax revenue to offset the $\$ 700$ million static revenue loss. Although the personal income tax revenue still declines by about $\$ 200$ million (column 3), this is offset by the greater payroll tax revenue (column 4).

With an overall revenue loss of $\$ 5.2$ billion and a deadweight loss reduction of $\$ 3.8$ billion, the deadweight loss reduction is about 72 cents per dollar of revenue loss (column 8 ). Raising the maximum second earner deduction also reduces the average marriage penalty.

Table 4 disaggreagates these results by five adjusted gross income class brackets. Although earnings rise at all income levels, more than half of the increase is among taxpayers with AGIs between $\$ 50,000$ and $\$ 100,000$. An additional one-third of the additional earnings is by couples with AGIs below $\$ 50,000$. The distribution of the static tax reductions is also 
concentrated on taxpayers with AGIs between $\$ 50,000$ and $\$ 100,000$. They receive more than half of the total static tax reduction. Less than $\$ 500$ million of the $\$ 7.9$ billion static revenue loss accrues to taxpayers with incomes over $\$ 200,000$.

It is interesting to compare the distribution of the static revenue loss and the distribution of the revenue loss with the behavioral change. In the lowest income class, the induced increase in earnings is enough to cause total taxes to rise. The middle bracket taxpayers still receive 50 percent of the overall tax reduction.

Comparing column 9 with column 1 of table 2 shows that the largest relative reduction in couples paying a marriage penalty occurs among those in the $\$ 25,000$ to $\$ 50,000$ AGI class. The decline in the number of marriage penalty couples in this group from 7.8 million to 6.8 million is about two-thirds of the overall decline in those paying a marriage penalty.

Table 5 shows the sensitivity of the revenue and deadweight loss estimates of the second earner deduction to alternative assumptions about labor supply elasticities. The first row repeats the baseline estimates shown in row 2 of Table 3 . The next row shows the effect of reducing the behavioral elasticities (both compensated and uncompensated) by 50 percent. The change in earnings is of course reduced by 50 percent, from $\$ 7.4$ billion to $\$ 3.7$ billion. Since the static revenue estimate does not depend on behavior, it remains unchanged. The revenue loss with behavior is now larger. Cutting the behavioral elasticities in half reduces the difference between the static revenue changes and the behavioral revenue changes with the baseline elasticities by 50 percent. But even with the elasticities reduced by 50 percent, the total revenue loss of $\$ 6.6$ billion is one-sixth smaller than the static revenue loss. The reduction in the deadweight loss declines from $\$ 3.8$ billion with the baseline elasticities to $\$ 2.8$ billion with the reduced 
elasticities. The reduction in deadweight loss per dollar of revenue loss is thus still 42 cents.

The effect of an increase in the behavioral elasticities is symmetrically higher. Earnings rise by $\$ 11$ billion and the revenue loss is limited to only $\$ 3.8$ billion. The change in the deadweight loss is $\$ 4.8$ billion, implying a reduction in deadweight loss of $\$ 1.26$ per dollar of revenue loss.

Because the estimates of the behavioral elasticities that we use are based on Eissa's analysis of the experience of relatively high income taxpayers, we consider another and more radical sensitivity analysis: assuming no behavioral response among taxpayers with incomes below $\$ 50,000$. The results are shown in row 4 . Even with no behavioral response among taxpayers with AGI below $\$ 50,000$, the second earner deduction causes earnings to rise by $\$ 5.2$ billion or 70 percent of the total for all taxpayers. The revenue loss with the baseline elasticities for those with AGIs over $\$ 50,000$ and zero elasticities for those with AGIs below $\$ 50,000$ is $\$ 6.7$ billion or $\$ 0.4$ billion more than when everyone is assumed to behave in the same way. The total revenue loss with behavior is $\$ 5.9$ billion, or $\$ 0.7$ billion more than when all are assumed to act in the same way. Thus even if we ignore the behavior of all taxpayers with AGIs less than $\$ 50,000$, behavior reduces the estimated revenue loss by 25 percent. The reduction in the deadweight loss is restricted to those with AGIs above $\$ 50,000$ since all others are assumed not to respond to the initial taxes. The resulting deadweight loss decline is $\$ 2.7$ billion, implying a deadweight loss reduction of 46 cents per dollar of revenue loss. 
Table 4

Distributional Effects of the Second Earner Deduction:

10 Percent of First $\$ 50,000$

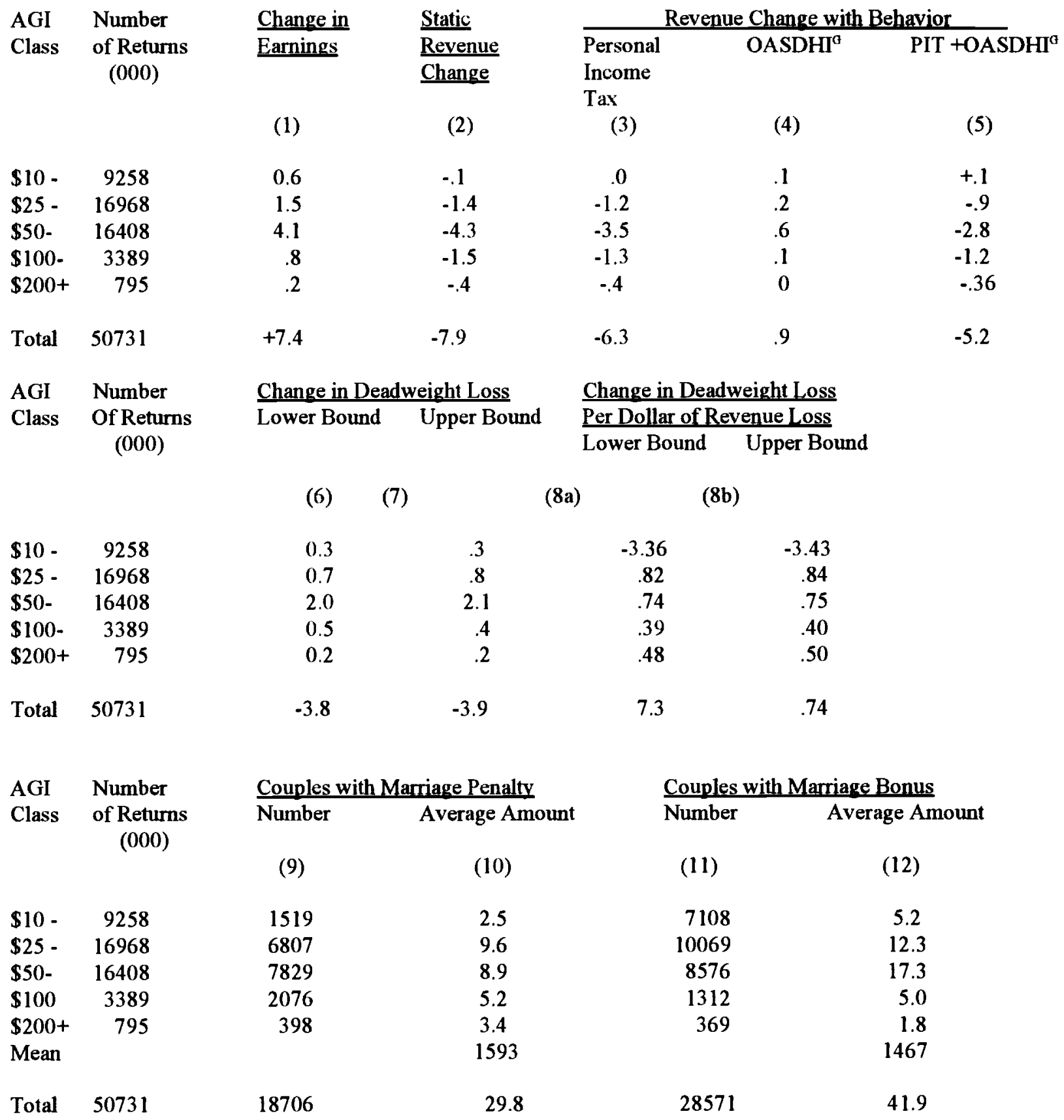

Amounts are in billions of dollars. All figures for 1994. Estimates are based on TAXSIM model calculations using the 1991 Treasury Public Use Sample aged to 1994 levels. 
The final analysis examines the sensitivity of the calculations to the assumption that individuals who are induced to enter the labor force by the second earner credit work the same number of hours as the existing employees. Row 5 shows the effect of reducing the average hours of these new entrants by 50 percent. The additional earnings induced by the more favorable tax rules are reduced by one-fifth and the revenue loss with behavioral responses increases from $\$ 5.2$ billion to $\$ 5.9$ billion. The improvement in the deadweight loss declines form $\$ 3.8$ billion to $\$ 2.7$ billion. Thus even with this reduction in hours for new participants, the second earner credit reduces the deadweight loss by 46 cents per dollar of revenue loss.

\subsection{Special Second Earner Flat Rate Tox Schedules}

The second earner deduction is an example of the differentially lower tax rate on second earners that optimal tax theory suggests. It achieves a significant reduction in the deadweight loss with a relatively modest cost in foregone revenue. We now present an alternative way of giving a lower tax rate to second earners by allowing the second earner to choose between her usual tax (up to the first $\$ 50,000$ of her wage income) and an optional flat rate tax on that income 
Table 5

\section{Sensitivity Analysis of Second Earner Deduction}

Row Description Change in

Static Revenue Change with Behavior Revenue PIT OASDHI ${ }^{\circ}$ PIT+OASDHI Change
Change in Deadweight Change in Deadweight Loss: Upper Bound Loss per Dollar of Revenue Loss

\begin{tabular}{|c|c|c|c|c|c|c|c|c|}
\hline & & (1) & (2) & (3) & (4) & (5) & (6) & $(7)$ \\
\hline 1 & Baseline & 7.4 & -7.9 & -6.3 & 1.1 & -5.2 & -3.8 & .72 \\
\hline \multirow[t]{2}{*}{2} & $\begin{array}{l}\text { Reduce } \\
\text { Elasticities }\end{array}$ & & & & & & & \\
\hline & by $50 \%$ & 3.7 & -7.9 & -7.1 & 0.6 & -6.6 & -2.8 & .42 \\
\hline \multirow[t]{2}{*}{3} & $\begin{array}{l}\text { Raise } \\
\text { Elasticities }\end{array}$ & & & & & & & \\
\hline & By $50 \%$ & 11.0 & -7.9 & -5.5 & 1.7 & -3.8 & -4.8 & 1.26 \\
\hline \multirow[t]{2}{*}{4} & $\begin{array}{l}\text { No Behavic } \\
\text { AGI < }\end{array}$ & & & & & & & \\
\hline & $\$ 50,000$ & 5.2 & -7.9 & -6.7 & 0.8 & -5.9 & -2.7 & .46 \\
\hline \multirow[t]{2}{*}{5} & $\begin{array}{l}\text { Reduce Ho } \\
\text { Of New } \\
\text { Entrants by }\end{array}$ & & & & & & & \\
\hline & $50 \%$ & 5.9 & -7.9 & -6.7 & 0.9 & -5.8 & -2.9 & .50 \\
\hline
\end{tabular}

Amounts are in billions of dollars. All figures for 1994. Estimates are based on TAXSIM model calculations using the 1991 Treasury Public Use Sample aged to 1994 levels. 
The first such option that we consider is an optional flat rate tax of 15 percent on the first $\$ 50,000$ of the second earner's wage income. Unlike the 10 percent deduction for second earners, this option is valuable only to a second earner who pays a marginal personal income tax rate in excess of 15 percent on at least part of her income. This is true only if the couple has taxable income of at least $\$ 38,000$; with two children, this corresponds to adjusted gross income of at least $\$ 54,150$. For those who do qualify, the marginal tax rate is reduced from 28 percent (or higher) to 15 percent unless the woman's earnings exceed $\$ 50,000$. Such a marginal tax rate reduction brings a substantial reduction in deadweight loss. ${ }^{34}$

The results are summarized in row 3 of Table 3 . The deadweight loss is reduced by at least $\$ 11.5$ billion (column 6) and perhaps by as much as $\$ 12.9$ billion (column 7). The greater relative gap between the lower and upper bounds reflects the larger reduction in the marginal tax rate, making it more difficult to be precise about the reservation wage for those who are not working now but who enter the labor force in response to the tax rate reduction. The substantial decline in the marginal tax rate also induces a $\$ 27.9$ billion rise in earnings, enough to reduce the revenue loss from the static $\$ 27.1$ billion (column 2) to a net loss of only $\$ 18.8$ billion (column 5). The optional 15 percent flat rate tax thus reduces the deadweight loss by between 61 cents and 69 cents per dollar of revenue loss.

The flat rate tax is more effective at reducing the marriage penalty, cutting the number of

${ }^{34}$ The woman might choose the optional tax even if it implied a higher tax burden at her initial level of earnings because it gives her the opportunity to increase her earnings at a lower marginal tax rate. Our analysis therefore understates both the efficiency gain and the revenue loss by assuming that taxpayers only take the optional rate when it lowers their tax liability on their original level of earnings. 
marriage penalty couples to 31 percent from the 36 percent with the second earner deduction and 40 percent under current law. This of course reflects not only the targeting of this tax reduction but also the much larger cost of this tax change.

The cost of an optional flat rate tax on part of the second earner's wage income can be reduced while maintaining the same simple structure of the plan by increasing the tax rate on the alternative flat rate tax. With an optional flat rate of 20 percent (instead of the 15 percent), a woman will choose the optional tax only if her average effective tax rate on the first $\$ 50,000$ of her income exceeds 20 percent. ${ }^{35}$ The results of this plan are shown in the fourth row of Table 3. The static revenue loss is cut nearly in half to $\$ 14.9$ billion and, with the $\$ 14.7$ billion projected rise in earnings, the net decline in total revenue is only $\$ 9.8$ billion. The static revenue loss overstates this projected revenue loss by more than 50 percent.

The efficiency gain is smaller than with the 15 percent flat tax but still implies a reduced deadweight loss between $\$ 7.0$ billion and $\$ 7.6$ billion. Comparing this to the $\$ 9.8$ billion net revenue loss indicates a reduction in the overall deadweight loss of between 71 cents per dollar of lost revenue and 77 cents per dollar of lost revenue

\subsection{Separate Filing by Husbands and Wives}

The most obvious alternative to the current tax treatment of two earner families is a rule that requires each individual to file a separate tax return. Designing a system of separate filing

\footnotetext{
${ }^{35}$ Once again, she might prefer the optimal tax because it allows her to earn a higher net wage even if she had to accept a smaller net of tax income on her initial earnings. The higher optional marginal tax rate would however still reduce the number of women who take the optional plan.
} 
involves decisions about the division between the husband and wife of nonlabor income and of itemized deductions. One option is to base the division of income on the ownership of underlying assets and the division of deductions on the individual who incurs the deductible expense. The income from jointly owned property would be divided in half as would joint deductible expenses (e.g., mortgage interest on a jointly owned house). Although advocates of this method recognize that couples could use interspousal transfers to reduce tax liabilities, they argue that such transfers of assets are real transfers, not likely to be entered into lightly in an age in which the ratio of divorces to marriages has reached 50 percent and more than a third of women in their forties who have been married have also been divorced. The alternative is to use arbitrary rules for dividing property income and deductions, either automatically assigning them to minimize tax burdens or merely dividing everything equally between the two spouses.

We do not have the underlying data on intrafamily asset ownership and expense patterns with which to allocate them between the spouses. Moreover, even if we had current information on income and expenses, it would not be appropriate to use that information to measure how those assets and expenses would be divided under a system that required separate filing based on the individual ownership of assets and individual deductions. We therefore adopt the rule that divides all nonlabor income, adjustments to gross income, deductible expenses, personal exemptions and tax credits equally between the husband and wife.

A shift from the current joint filing requirement to mandatory separate filing also requires a decision about the tax rates to be used at each level of income. We present four alternative analyses. The first permits the primary earner to continue to use the current schedule for joint filers while the second earner uses a special new schedule equal to 60 percent of the 
current single filer's rate at each level of taxable income. For many women, filing a separate tax return with half of the deductions and exemptions for the family means paying no tax at all. The marginal tax rate drops from 15 percent, 28 percent or higher to zero. Although the lower marginal tax rate can induce a substantial reduction in deadweight loss, it also involves a very large revenue loss. Since much of that loss is associated with the decrease from the 15 percent tax bracket, it is relatively inefficient way of reducing deadweight loss. These characteristics are reflected in the estimates presented in row 5 of Table 3.

Column 2 shows that the static revenue loss would be $\$ 65.2$ billion. Although the reduced marginal tax rates induce an earnings rise of $\$ 65.6$ billion, the personal income tax loss is only reduced very slightly (to $\$ 59.0$ billion, as shown in column 3 ) because much of the additional earnings are earned by women who, after the reform, would not be subject to any tax at all because they would file separately with half of the deductions and exemptions of the family. Even with additional payroll tax revenue of $\$ 9.5$ billion, the net revenue loss is $\$ 49.5$ billion.

The reduction in the deadweight loss is at least $\$ 18.4$ billion and could be as large as $\$ 27.3$ billion. The much greater uncertainty about the magnitude of the reduced deadweight loss reflects the sharp drop in the marginal tax rate, often from 28 percent or higher to zero. The lower and upper bounds imply that this option would reduce the deadweight loss by between 37 cents and 55 cents per dollar of revenue, substantially less than the other proposals that did not involve the possibility of a zero tax rate.

Option 6 is similar to option 5 but only reduces the tax rates on the single earner schedule to 80 percent of their current values. Although this seems like a substantial reduction in the tax 
advantage to the second earner, that is not true for those who do not have taxable income. Similarly, the primary earner continues to get the advantage of paying tax on a much reduced taxable income at the joint filer tax rates. The result is a continued large revenue loss and a relatively unfavorable ratio of efficiency gain per dollar of revenue loss.

Line 6 of Table 3 shows that the $\$ 55.6$ billion increase in earnings only induces a net increase in revenue of $\$ 6.3$ billion, a clear indication that most of the increased earnings are to women in the zero marginal tax rate bracket. Even when the additional payroll tax revenue is recognized, the net revenue loss is still $\$ 40.1$ billion. The change in deadweight loss is therefore only between 38 cents and 60 cents per dollar of revenue loss.

The final two rules are designed to be revenue neutral when the behavioral response of the married women is taken into account. The first of these requires mandatory separate filing by husbands and wives using the tax brackets of the joint return but with all tax rates multiplied by 1.11. The results are shown in line 7 of Table 3. The women's earnings rise by $\$ 45.5$ billion, cutting the loss in personal income tax revenue from the $\$ 12.5$ billion static estimate to $\$ 6.9$ billion. This is completely offset by the additional $\$ 6.9$ billion of payroll tax revenue. Despite the revenue neutrality, the deadweight loss is reduced by between $\$ 13.2$ billion and $\$ 19.3$ billion. Since many women would still find themselves paying no tax, the revenue neutrality is achieved by increasing the tax rates on their husbands who face the rescaled single taxpayer schedule instead of the more favorable joint filer schedule. The remaining small static revenue loss in the income tax is just offset by the additional OASDHI tax collected as a result of the higher earnings of the married women. This analysis does of course reflect the strong (but 
traditional) assumption that the labor supply of husbands is completely inelastic. ${ }^{36}$

The final revenue-neutral income splitting option that we present (row 8 of table 3 ) uses the tax rate brackets of the single taxpayer schedule but reduces all rates to 92.9 percent of existing statutory rates. The results are quite similar to those of row 7 based on the joint taxpayer schedule.

\subsection{Eliminating the Second Earner Social Security Tax Burden}

The current method of calculating Social Security benefits has the effect of giving married women very little additional benefit in return for the extra payroll taxes that they pay when they work more. As we noted earlier in the paper, this has the effect of making the married woman's marginal tax rate substantially higher than her husband's. In this section we consider the effect of eliminating the actuarially unfair burden of Social Security on married women by excluding married women from the OASDHI tax base. ${ }^{37}$

The final row of Table 3 shows that the resulting reduction in marginal tax rates would cause earnings to rise by $\$ 37.9$ billion and would reduce the deadweight loss of the tax system by at least $\$ 17.1$ billion. Eliminating the Social Security tax on married women does however

${ }^{36} \mathrm{We}$ recognize that the assumption that husbands do not respond to their higher marginal tax rates is unrealistic. A realistic analysis would recognize that husbands as well as wives respond to changes in marginal tax rates by altering the character of their work and the pattern of their consumption. We will provide a more realistic analysis in a future paper that takes such broader behavior into account.

${ }^{37}$ This could be achieved in practice by a rebatable credit equal to the full Social Security tax liability. Married women would continue to receive benefits on the basis of their husbands' income as most of them now do. We do not consider the effect of the tax paid by the married woman in other years when she was not married. 
reduce payroll tax revenue by $\$ 51.4$ billion. The offsetting revenue gain of $\$ 8.5$ billion of additional personal income tax revenue leaves a net revenue loss of $\$ 42.9$ billion, implying that the deadweight burden reduction is between 39 cents and 46 cents per dollar of revenue loss, similar to the efficiency of the separate filing options and less cost-effective than the second earner deduction.

\section{Concluding Comments}

Three general conclusions emerge from analyzing the simulations of the various options presented in this paper. First, the existing high marginal tax rates on married women cause substantial deadweight losses that can be reduced by alternative tax rules that lower their marginal tax rates. Second, the behavioral responses to the lower marginal tax rates induce additional tax payments that offset large fractions of the "static" revenue losses. Third, there are substantial differences in cost-effectiveness among these options, i.e., in the revenue cost per dollar of reduced deadweight loss. Several of the options are sufficiently cost-effective that they could probably be combined with other ways of raising revenue to produce a net reduction in the deadweight loss of the tax system as a whole.

We are aware however that the current framework is very restrictive in three important ways. First, it ignores the response of the primary earner in the couple to any change in tax rates or spousal income. Second, it defines the labor supply response very narrowly in terms of participation and hours, excluding such important dimensions of labor supply as choice of occupation and of particular job, effort, location, travel requirements, risk bearing, assumption of responsibility, etc.. More generally, taxes affect not only the labor supply of men and women 
but also change taxable income through changes in excluded income (fringe benefits, etc.) and in taxpayer deductions. These changes in taxable income are the key variable for influencing tax revenue. Moreover, the deadweight loss of the tax system depends not just on the change in the amount of labor that individuals choose to supply but also on the induced changes in the amounts of excludible income and deductible expenses (Feldstein , 1995a). We plan to extend the current work to merge the evidence on the effects of taxes on the hours and participation of married women with the more general evidence on the sensitivity of taxable income to marginal tax rates.

\section{Cambridge MA}

January 1995

Revised May 1995 


\section{References}

Boskin, Michael J. and Eytan Sheshinski, "Optimal Tax Treatment of the Family: Married Couples, Journal of Public Economics, Vol. 20, pp 281-297, April 1983.

Browning, Edgar K., "On the Marginal Welfare Cost of Taxation," American_Economic Review, Vol. 77, No. 1, pp 11-23, March 1987.

Eissa, Nada, "Taxation and Labor Supply of Married Women: The Tax Reform Act of 1986 as a Natural Experiment," NBER Working Paper No. 5023.

Feenberg, Daniel R. and Harvey S. Rosen, "Alternative Tax Treatments of the Family: Simulation Methodology and Results," Behavioral Methods in Tax Policy Analysis, (ed.) Martin Feldstein, Chicago: University of Chicago Press, 1983.

Feenberg, Daniel R. and Harvey S. Rosen, "Recent Developments in the Marriage Tax, " NBER Working Paper No. 4705, March 1994, National Tax Journal, 48(1), pp 91-101.

Feldstein, Martin, "The Effect of Marginal Tax Rates on Taxable Income: A Panel Study of the 1986 Tax Reform Act," Journal of Political Economy, June 1995.

Feldstein, Martin, "The Case for Dynamic Analysis, " Wall Street Journal, December 14, 1994.

Feldstein, Martin, "Tax Avoidance and the Deadweight Loss of the Income Tax," NBER Working Paper No. 5000 (1995a).

Feldstein, Martin, "Revenue Estimation and Tax Policy," forthcoming (1995b).

Feldstein, Martin, "Revenue Estimates Should Reflect the Effect of Taxes on Work and Saving," Testimony to the Joint Hearing of the Senate Budget Committee and the House Budget Committee, U.S. Congress, January 10, 1995.

Feldstein, Martin and Andrew Samwick, "Social Security Rules and Marginal Tax Rates," (with Andrew Samwick), National Tax Journal, Vol. XLV, No. 1, pp 1-21, March 1992.

Harberger, Arnold, "Taxation, Resource Allocation, and Welfare," in The Role of Direct and Indirect Taxes in the Federal Revenue System," Princeton University Press, Princeton, NJ, 1964.

Hausman, Jerry and Paul Ruud, "Family Labor Supply with Taxes," American Economic Review, Vol. 74, No. 2, pp 242-248, May 1984. 
Munnell, Alicia, "The Couple versus the Individual Under the Personal Income Tax," in H. Aaron and M. Boskin, eds., The Economics of Taxation, Washington, DC: The Brookings Institution.

Rosen, Harvey, "A Methodology for Evaluating Tax Reform Proposals," Journal of Public Economics, Vol. 6, No. 1-2, pp 105-121, July/August 1976.

Rosen, Harvey, "The Marriage Tax is Down But Not Out, " National Tax Journal, Vol. 40, No. 4, pp 567-576, December 1987.

Triest, Ronald, "The Effect of Income Taxation on Labor Supply in the United States," The Journal of Human Resources, Vol 25, No. 3, pp 491-516, Summer 1990. 